\title{
PENGARUH PENGGUNAAN BERBAGAI KOAGULAN KIMIA PADA LIMBAH CAIR KELAPA SAWIT (Elaeis guineensis Jacq.) TERHADAP PENURUNAN BEBAN PENCEMAR
}

\author{
Imam Fatoni' ${ }^{1}$, Rijadi Subiantoro ${ }^{2}$, Maryanti ${ }^{3}$ \\ ${ }^{1}$ Program Studi Produksi Dan Manajemen Industri Perkebunan Politeknik Negeri Lampung, \\ 2Jurusan Budidaya Tanaman Perkebunan, Politeknik Negeri Lampung \\ 3)Jurusan Budidaya Tanaman Perkebunan, Politeknik Negeri Lampung \\ Jl. Soekarno Hatta No.10 Rajabasa, Bandar lampung, 35144, Telp,:0721) 703995, \\ E-mail: imamfatoni873@gmail.com
}

\begin{abstract}
The Effect Of The Use Of A Variety Of Chemical Coagulants On The Palm Oil Waste (Elaeis guineensis Jacq.) On Pollution Loads. Oil palm (Elaeis guineensis Jacq.) Is a type of plantation that is Indonesia's mainstay commodity with rapid development. Palm oil industry wastewater comes from a variety of palm oil processing processes that contain high organic and inorganic materials. The resulting waste must be controlled and treated so that it does not pose a threat to the palm oil industry because it can pollute the environment and sources of disease. One method of processing palm oil liquid waste that can be used is coagulation. The coagulation process requires a coagulant, the coagulant used is aluminum sulfate, ferrous sulfate, ferric chloride. This study aims to obtain the type and dose of chemical coagulants that are effective in handling palm oil industry liquid waste in anaerobic ponds and determine the reduction of pollutant variables (COD, TSS, Turbdity, color, and $\mathrm{pH}$ changes) due to the treatment of coagulant treatment. This study used a Randomized Group Design (RBD) with 10 levels of treatment consisting of BO (Noncoagulant), B1 $\left(\mathrm{Al}_{2}\left(\mathrm{SO}_{4}\right)_{3} 1 \mathrm{~g} / \mathrm{L}\right), \mathrm{B2}\left(\mathrm{Al}_{2}\left(\mathrm{SO}_{4}\right)_{3} \mathrm{1,5} \mathrm{g} / \mathrm{L}\right), \mathrm{B3}\left(\mathrm{Al}_{2}\left(\mathrm{SO}_{4}\right)_{3} 2 \mathrm{~g} / \mathrm{L}\right), \mathrm{B} 4$ $\left(\mathrm{FeSO}_{4} 7 \mathrm{H}_{2} \mathrm{O} 1 \mathrm{~g} / \mathrm{L}\right), \mathrm{B5}\left(\mathrm{FeSO}_{4} 7 \mathrm{H}_{2} \mathrm{O} \mathrm{1,5} \mathrm{g} / \mathrm{L}\right), \mathrm{B}\left(\mathrm{FeSO}_{4} 7 \mathrm{H}_{2} \mathrm{O} 2 \mathrm{~g} / \mathrm{L}\right), \mathrm{B} 7\left(\mathrm{FeCl}_{3} 6 \mathrm{H}_{2} \mathrm{O} 1 \mathrm{~g} / \mathrm{L}\right)$, $B 8\left(\mathrm{FeCl}_{3} 6 \mathrm{H}_{2} \mathrm{O} 1,5 \mathrm{~g} / \mathrm{L}\right), \mathrm{B} 9\left(\mathrm{FeCl}_{3} 6 \mathrm{H}_{2} \mathrm{O} 1 \mathrm{~g} / \mathrm{L}\right)$. Data were analyzed by analysis of variance (ANOVA) and a 5\% LSD test. The results obtained are ferric chloride being the best coagulant to reduce polluted parameters in palm oil liquid waste and Ferri chloride $2 \mathrm{~g} / \mathrm{L}$ is the best treatment for reducing pollutant parameters of COD, TSS, Turbidity, and Color. Whereas the best $\mathrm{pH}$ reduction in aluminum sulfate $1 \mathrm{~g} / \mathrm{L}$ coagulant.
\end{abstract}

Keywords: Palm Oil Mill Liquid Waste, Coagulant; Coagulation

Abstrak: Pengaruh Penggunaan Berbagai Koagulan Kimia Pada Limbah Cair Kelapa Sawit (Elaeis guineensis Jacq.) Terhadap Penurunan Beban Pencemar. Kelapa sawit (Elaeis guineensis Jacq.) merupakan jenis tanaman perkebunan yang menjadi komiditi andalan Indonesia dengan perkembangan yang pesat. Limbah cair industri kelapa sawit berasal dari berbagai proses pengolahan kelapa sawit yang mengandung bahan organik dan anorganik tinggi. Limbah yang dihasilkan harus dikendalikan dan diolah agar tidak menjadi ancaman bagi industri kelapa sawit karena dapat mencemari lingkungan dan sumber penyakit. Salah satu metode pengolahan limbah cair kelapa sawit yang dapat digunakan adalah koagulasi. Proses koagulasi memerlukan koagulan, koagulan yang di gunakan adalah alumunium sulfat, ferrous sulfate, ferri chloride. Penelitian ini bertujuan untuk mendapatkan jenis dan dosis koagulan kimia yang efektif dalam penanganan limbah cair industri kelapa sawit pada kolam anaerob dan mengetahui reduksi variabel pencemar (COD, TSS, Turbdity, warna, dan perubahan $\mathrm{pH}$ ) akibat perlakuan pemberian koagulan. Penelitian ini menggunakan Rancanagan Acak Kelompok (RAK) dengan 10 taraf perlakuan yang terdiri dari $B O$ (Non koagulan), $\mathrm{B} 1\left(\mathrm{Al}_{2}\left(\mathrm{SO}_{4}\right)_{3} 1 \mathrm{~g} / \mathrm{L}\right), \mathrm{B} 2\left(\mathrm{Al}_{2}\left(\mathrm{SO}_{4}\right)_{3} \mathrm{H}_{5} \mathrm{~g} / \mathrm{L}\right), \mathrm{B} 3\left(\mathrm{Al}_{2}\left(\mathrm{SO}_{4}\right)_{3} 2 \mathrm{~g} / \mathrm{L}\right), \mathrm{B} 4$ $\left(\mathrm{FeSO}_{4} 7 \mathrm{H}_{2} \mathrm{O} 1 \mathrm{~g} / \mathrm{l}\right), \mathrm{B5}\left(\mathrm{FeSO}_{4} 7 \mathrm{H}_{2} \mathrm{O}\right.$ 1,5 g/l), $\mathrm{B} 6\left(\mathrm{FeSO}_{4} 7 \mathrm{H}_{2} \mathrm{O} 2 \mathrm{~g} / \mathrm{l}\right), \mathrm{B} 7\left(\mathrm{FeCl}_{3} 6 \mathrm{H}_{2} \mathrm{O} 1 \mathrm{~g} / \mathrm{ll}\right), \mathrm{B} 8$ ( $\mathrm{FeCl}_{3} 6 \mathrm{H}_{2} \mathrm{O}$ 1,5 g/l), $\mathrm{B} 9$ ( $\left.\mathrm{FeCl}_{3} 6 \mathrm{H}_{2} \mathrm{O} 2 \mathrm{~g} / \mathrm{l}\right)$. Data dianalisis dengan sidik ragam (ANOVA) dan uji lanjut BNT 5\%. Hasil yang diperoleh adalah ferri chloride menjadi koagulan terbaik untuk menurunkan parameter tercemar pada limbah cair kelapa sawit dan Ferri chloride $2 \mathrm{~g} / \mathrm{L}$ merupakan perlakuan paling baik untuk menurunkan parameter 
pencemar COD, TSS, Turbidity, dan Warna. Sedangkan penurunan $p H$ terbaik pada koagulan alumunium sulfate $1 \mathrm{~g} / \mathrm{L}$.

Kata kunci: Limbah Cair Pabrik Kelapa Sawit; Koagulan; Koagulasi

\section{PENDAHULUAN}

Kelapa sawit (Elaeis guineensis Jacq.) merupakan jenis tanaman perkebunan yang menempati posisi penting dalam sektor pertanian dan perkebunan yang menjadi komiditi andalan Indonesia dengan perkembangan yang pesat (Pahan, 2006). Luas areal perkebunan kelapa sawit di Indonesia selama enam tahun terakhir menunjukan peningkatan sekitar 2,77 sampai dengan 11,33 persen per tahun. Pada tahun 2010 tercatat seluas 8,55 juta hektar meningkat menjadi 10,75 juta hektar pada tahun 2014 atau sebesar 25,80 persen. Pada tahun 2015 luas areal perkebunan kelapa sawit diperkirakan meningkat sebesar 5,07 persen dari tahun 2014 menjadi 11,30 juta hektar(BPS Pusat, 2015).

Sejalan dengan meningkatnya produksi sawit di Indonesia dari tahun ke tahun, maka akan terjadi peningkatan volume limbah yang dihasilkan. Limbah yang dihasilkan berupa limbah padat dan limbah cair. Satu ton kelapa sawit menghasilkan limbah berupa tandan kosong kelapa sawit sebanyak $23 \%$ atau $230 \mathrm{~kg}$, limbah cangkang (shell) sebanyak 6,5\% atau 65 $\mathrm{kg}$, wet decanter solid (lumpur sawit) $4 \%$ atau $40 \mathrm{~kg}$, serabut (fiber) $13 \%$ atau $130 \mathrm{~kg}$ serta limbah cair sebanyak 50\% dan untuk CPO sebesar 3,5\% atau $35 \mathrm{~kg}$. (Mandiri, 2012). Limbah yang dihasilkan tersebut harus dikendalikan dan diolah agar air yang dibuang keluar atau ke sungai nantinya tidak mencemari lingkungan. Limbah cair menjadi ancaman bagi industri sawit karena dapat dipastikan mencemari lingkungan khususnya air tanah dan dapat menjadi sebagai media pembawa penyakit.

Kandungan yang terdapat dalam limbah cair kelapa sawit berupa bahan organik dan anorganik cukup tinggi. Semua parameter limbah cair Pengolahan Minyak Kelapa Sawit (PMKS) berada di atas ambang batas baku mutu limbah. Limbah cair tersebut apabila tidak dilakukan pengolahan maka akan berdampak negatif pada lingkungan seperti pencemaran air yang mampu meracuni biota perairan, menimbulkan bau, dan menghasilkan gas methan dan $\mathrm{CO}_{2}$ yang merupakan emisi gas penyebab efek rumah kaca yang berbahaya bagi lingkungan (Yulastri, dkk., 2013).

Salah satu metode pengolahan limbah cair kelapa sawit yang dapat digunakan adalah koagulasi. Koagulasi merupakan proses dengan memanfaatkan ion-ion yang mempunyai muatan berlawanan dengan muatan koloid yang terkandung dalam limbah cair, sehingga dapat menghilangkan kestabilan ion. Prinsip dasar dari koagulasi adalah gaya tarik menarik antara ion positif dan negatif. Ion negatif adalah partikel yang terdiri dari zat organik, mikroorganisme dan bakteri (Bangun, dkk., 2013). Mekanisme pembentukan flok-flok dalam proses koagulasi-flokulasi terdiri dari tiga tahap, yaitu tahap destabilisasi partikelpartikel koloid, tahap pembentukan mikrofilik dan tahap pembentukan makrofilik. Tahap pertama dan kedua berlangsung selama proses koagulasi, sedangkan tahap ketiga berlangsung selama proses flokulasi. Pembentukan makrofilik dalam proses flokulasi terjadi karena tumbukan-tumbukan antara partikel koloid.

Poses koagulasi memerlukan koagulan. Koagulan adalah bahan kimia yang ditambahkan ke dalam air untuk dapat mengendapkan partikel koloid yang sulit terhilangkan didalam air. Koagulan digunakan dalam proses koagulasi untuk menjaga kestabilitasan muatan dengan menekan atau menghilangkan lapisan diffused layer sehingga yang tersisa adalah gaya tarik menarik antar partikel Van Der Waals (Prihatinningtyas, 2013).

Ada beberapa jenis koagulan yang dapat digunakan diantaranya alumunium sulfate, ferric Chloride, dan ferous Sulfate. Namun dosis koagulan yang tepat untuk limbah cair kelapa sawit belum diketahui, oleh karena itu perlu dilakukan penelitian jenis dan dosis koagulan yang tepat dalam 
mereduksi kandungan limbah cair kelapa sawit.

\section{BAHAN DAN CARA PENELITIAN}

Penelitian telah dilaksanakan di Laboratorium Analisis Politeknik Negeri Lampung, pada bulan Agustus 2019 sampai September 2019. Alat yang digunakan dalam penelitian ini jerigen, turbidity meter, biuret, alat jar test seperti : stopwatch, $\mathrm{pH}$ meter, buku munsell, neraca analitik, dan beakerglass $1000 \mathrm{ml} 9$ buah, spatula, pipet $10 \mathrm{ml}$, bola hisap, cawan, erlenmeyer, oven. Bahan yang digunakan adalah limbah cair kelapa sawit dari kolam anaerob yang ke 2, alumunium sulfate (tawas), ferrous sulfate $\left(\mathrm{FeSO}_{4} 7 \mathrm{H}_{2} \mathrm{O}\right)$, ferric cloride $\left(\mathrm{FeCl}_{3} 6 \mathrm{H}_{2} \mathrm{O}\right)$, aquades, $\mathrm{MnSO}_{4}, \mathrm{H}_{2} \mathrm{SO}_{4}$, $\mathrm{K}_{2} \mathrm{Cr}_{2} \mathrm{O}_{7}, \mathrm{HgSO}_{4}$, larutan kalium hidrogen, larutan pencerna, kertas saring whatman, FAS dan indikator feroin.

Penelitian ini menggunakan Rancangan acak kelompok ( RAK ) yang terdiri dari 10 perlakuan yaitu : B0 : (Non koagulan), B1 : Koagulan alumunium sulfate (tawas) $1 \mathrm{~g} / \mathrm{l}, \mathrm{B} 2$ : Koagulan alumunium sulfate (tawas) 1,5 g/l, B3 : Koagulan alumunium sulfate (tawas) $2 \mathrm{~g} / \mathrm{l}, \mathrm{B} 4$ :
Koagulan ferrous sulfate $\left(\mathrm{FeSO}_{4} 7 \mathrm{H}_{2} \mathrm{O}\right) 1$ $\mathrm{g} / \mathrm{l}, \mathrm{B} 5$ : Koagulan ferrous sulfate $\left(\mathrm{FeSO}_{4} 7 \mathrm{H}_{2} \mathrm{O}\right)$ 1,5 g/l, B6 : Koagulan ferrous sulfate $\left(\mathrm{FeSO}_{4} 7 \mathrm{H}_{2} \mathrm{O}\right) 2 \mathrm{~g} / \mathrm{l}, \mathrm{B} 7$ : Koagulan ferric chloride $\left(\mathrm{FeCl}_{3} 6 \mathrm{H}_{2} \mathrm{O}\right) 1 \mathrm{~g} / \mathrm{l}, \mathrm{B} 8$ : Koagulan ferric chloride $\left(\mathrm{FeCl}_{3} 6 \mathrm{H}_{2} \mathrm{O}\right) 1,5 \mathrm{~g} / \mathrm{l}$, B9 : Koagulan ferric chloride $\left(\mathrm{FeCl}_{3} 6 \mathrm{H}_{2} \mathrm{O}\right) 2$ g/l. Dari 10 perlakuan diulang sebanyak 3 kali dan masing-masing satuan percobaan terdiri dari 1 beaker gelas sehingga terdapat 30 satuan percobaan dengan keseluruhan terdapat 30 beaker gelas. Jika hasil analisis sidik ragam menunjukkan perbedaan signifikan nyata diantara perlakuan, maka akan dilakukan uji lanjut dengan BNT pada taraf 5\%.

\section{HASIL PENELITIAN DAN PEMBAHASAN}

\section{Uji Pendahulan Limbah Cair Kelapa Sawit}

Limbah cair kelapa sawit dari PTPN VII Unit Usaha Bekri pada kolam anaerob yang ke 2 memiliki karakteristik parameter tercemar. Berdasarkan uji pendahuluan yang telah dilakukan, nilai parameter tercemar tersebut disajikan pada Tabel 3.

Tabel 3 Hasil uji pendahuluan limbah cair kelapa sawit pada kolam anaerob.

\begin{tabular}{|c|c|c|}
\hline No & Parameter & Nilai \\
\hline 1 & COD ( mg/L) & 21.333 \\
\hline 2 & $\mathrm{pH}$ & 7,04 \\
\hline 3 & TSS (mg/L) & 882 \\
\hline 4 & Turbidity (NTU) & 1.154 \\
\hline 5 & Warna & Olive black ( hitam kecoklatan) \\
\hline
\end{tabular}

\section{Pengaruh Jenis dan Dosis Koagulam Terhadap Nilai Chemical Oxygen Demand (COD)}

COD adalah jumlah total oksigen yang dibutuhkan untuk mengoksidasi semua bahan organik yang terdapat didalam sumberdaya perairan menjadi $\mathrm{CO}_{2}$ dan $\mathrm{H}_{2} \mathrm{O}$. Nilai COD akan menurun sejalan dengan penurunan kandungan bahan organik diperairan yang disebabkan karena pengendapan padatan yang terdapat pada air limbah. Variasi dosis koagulan alumunium sulfate, ferrous sulfate dan ferric chloride adalah bermacam dosis koagulan yang digunakan dalam perlakuan dengan satuan gr/L yang artinya dalam gram koagulan dimasukkan kedalam 1 liter air limbah kelapa sawit.

Hasil analisis ragam menunjukkan bahwa pemberian koagulan alumunium sulfate, ferrous sulfate dan ferric chloride memberikan pengaruh nyata terhadap nilai chemical oxygen demand (COD). Hasil uji lanjut BNT pada taraf 5\% disajikan pada Tabel 4. 
Tabel 4. Hasil uji rataan perlakuan koagulan terhadap nilai chemical cxygen demand (COD)

\begin{tabular}{clc}
\hline No & \multicolumn{1}{c}{ Perlakuan } & Nilai COD $(\mathrm{mg} / \mathrm{L})$ \\
\hline 1 & non koagulan & $7.110,67 \mathrm{~b}$ \\
2 & alumunium sulfate $1 \mathrm{~g}$ & $6.666,00 \mathrm{~b}$ \\
3 & alumunium sulfate $1,5 \mathrm{~g}$ & $6.221,67 \mathrm{~b}$ \\
4 & alumunium sulfate $2 \mathrm{~g}$ & $5.777,33 \mathrm{~b}$ \\
5 & ferrous sulfate $1 \mathrm{~g}$ & $7.555,33 \mathrm{~b}$ \\
6 & ferrous sulfate $1,5 \mathrm{~g}$ & $7.110,67 \mathrm{~b}$ \\
7 & ferrous sulfate 2 g & $6.666,00 \mathrm{~b}$ \\
8 & ferric chloride 1 g & $5.777,33 \mathrm{~b}$ \\
9 & ferric chloride 1,5 g & $5.333,00 \mathrm{~b}$ \\
10 & ferric chloride 2 g & $2.666,00 \mathrm{a}$ \\
\hline BNT 0,05 & & 877,71 \\
\hline
\end{tabular}

Keterangan : Nilai rata-rata pada kolom yang sama diikuti huruf yang sama menunjukkan tidak berbeda nyata berdasarkan hasil uji BNT taraf 5\%.

Berdasarkan hasil uji BNT 5\% terhadap nilai COD dari pemberian koagulan menunjukkan hasil yang berbeda nyata pada perlakuan ferric chloride $2 \mathrm{~g}$ dengan perlakuan alumunium sulfate dan ferrous sulfate. Pemberian koagulan memberikan pengaruh terhadap nilai COD yang dapat dilihat pada Gambar 6.

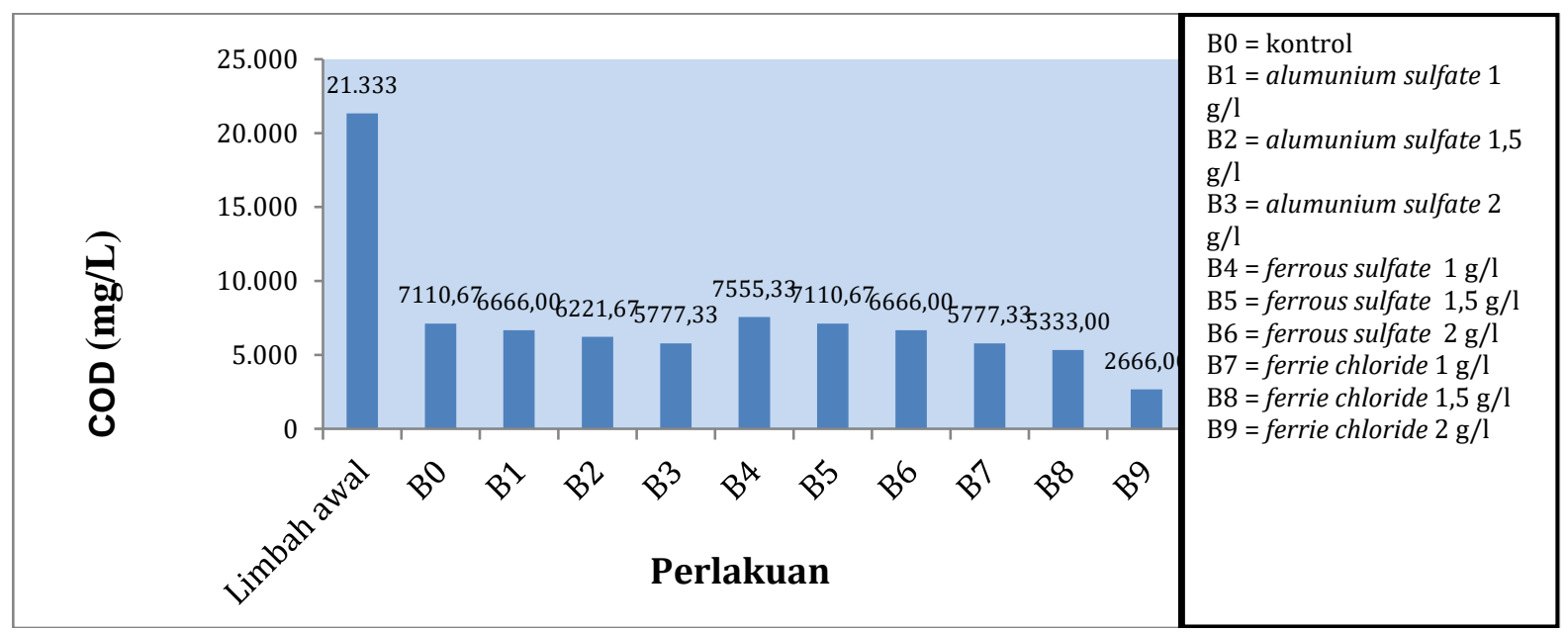

Gambar 6. Nilai COD dari limbah cair kelapa sawit akibat perlakuan

Gambar 6, menunjukkan bahwa terjadinya penurunan nilai parameter COD limbah cair kelapa sawit disebabkan karena adanya proses koagulasi antara koagulan dengan partikel-partikel koloid pada limbah cair kelapa sawit berupa zat organik. Nilai COD limbah cair industri kelapa sawit yang awalnya $21.333 \mathrm{mg} / \mathrm{L}(0 \%)$ setelah diberi penambahan dosis koagulan alumunium sulfate $2 \mathrm{~g} / \mathrm{L}$, nilai COD menjadi 5.777,33 $\mathrm{mg} / \mathrm{L}$ terjadi removal hingga $73 \%$. Pada penambahan dosis koagulan ferrous sulfate $2 \mathrm{~g} / \mathrm{L}$, nilai COD menjadi $6.666 \mathrm{mg} / \mathrm{L}$ terjadi removal hingga $69 \%$. Sedangkan penambahan dosis koagulan ferric chloride $2 \mathrm{~g} / \mathrm{L}$, nilai COD menjadi $2.666 \mathrm{mg} / \mathrm{L}$ terjadi removal hingga $87 \%$. Untuk non koagulan mengalami penurunan $66,67 \%$, penurunan ini terjadi karena adanya proses pengadukan cepat dan pengadukan lambat, serta pengendapan.

Menurut Kristijarti, dkk., 2013, ferrous sulfate merupakan koagulan bersifat positif sehingga dapat melemahkan gaya tolak-menolak antar partikel koloid yang bermuatan negatif. Ketika elektrolit diserap partikel koloid dalam air, ferrous sulfate dapat menurunkan bahkan menghilangkan 
kekokohan partikel koloid dan menetralkan muatannya. Penetralan muatan partikel oleh koagulan hanya mungkin terjadi jika muatan partikel mempunyai konsentrasi yang cukup untuk mengadakan gaya tarikmenarik antar partikel koloid, sehingga penggunaan ferrous sulfat sebagai koagulan pada limbah kelapa sawit tidak mampu menurunkan nilai COD secara signifikan.

Pada $\mathrm{pH}$ rendah proses koagulasi kurang optimal sehingga penambahan alkali seperti $\mathrm{Ca}(\mathrm{OH})_{2}$ dan $\mathrm{NaOH}$ diperlukan untuk mempertahankan $\mathrm{pH}$ agar tetap berada dalam batas daerah yang baik untuk koagulasi. Apabila garam besi seperti ferrous sulfat dipergunakan sebagai koagulan maka besi akan bereaksi dengan kandungan alkali yang terdapat didalam limbah membentuk besi hidroksida yang berpengaruh dalam proses koagulasi (Rusdianto, 2007).

\section{Pengaruh Jenis dan Dosis Koagulam Terhadap Nilai pH}

Derajat kemasaman $(\mathrm{pH})$ adalah untuk menyatakan tingkat keasaman atau kebasaan yang dimiliki oleh suatu larutan. Nilai pH berkisar dari 0 hingga 14. Suatu larutan dikatakan netral apabila memiliki nilai $\mathrm{pH}$ 7. Nilai $\mathrm{pH}$ lebih dari 7 menunjukkan larutan memiliki sifat basa, sedangkan nilai $\mathrm{pH}$ kurang dari 7 menunjukkan keasaman.

Hasil analisis ragam menunjukkan bahwa pemberian koagulan alumunium sulfate, ferrous sulfate dan ferric chloride memberikan pengaruh nyata terhadap nilai pH. Hasil uji lanjut BNT pada taraf $5 \%$ disajikan pada Tabel 5 .

Tabel 5. Hasil uji rataan perlakuan koagulan terhadap nilai pH

\begin{tabular}{|c|c|c|}
\hline No & Perlakuan & Nilai pH \\
\hline 1 & non koagulan & $6,86 \mathrm{~b}$ \\
\hline 2 & alumunium sulfate $1 \mathrm{~g}$ & $6,96 \mathrm{~b}$ \\
\hline 3 & alumunium sulfate $1,5 \mathrm{~g}$ & $6,88 \mathrm{~b}$ \\
\hline 4 & alumunium sulfate $2 \mathrm{~g}$ & $6,70 \mathrm{~b}$ \\
\hline 5 & ferrous sulfate $1 \mathrm{~g}$ & $6,83 \mathrm{~b}$ \\
\hline 6 & ferrous sulfate $1,5 \mathrm{~g}$ & $6,87 \mathrm{~b}$ \\
\hline 7 & ferrous sulfate $2 \mathrm{~g}$ & $6,78 \mathrm{~b}$ \\
\hline 8 & ferric chloride $1 \mathrm{~g}$ & $6,52 \mathrm{~b}$ \\
\hline 9 & ferric chloride $1,5 \mathrm{~g}$ & $6,29 a$ \\
\hline 10 & ferric chloride $2 \mathrm{~g}$ & $6,17 \mathrm{a}$ \\
\hline BNT 0,05 & & 0,35 \\
\hline
\end{tabular}

Keterangan : Nilai rata-rata pada kolom yang sama diikuti huruf yang sama menunjukkan tidak berbeda nyata berdasarkan hasil uji BNT taraf 5\%.

Berdasarkan hasil uji BNT 5\% terhadap nilai pH dari pemberian koagulan menunjukkan hasil yang berbeda nyata pada perlakuan ferric chloride 1,5 g dan ferric chloride $2 \mathrm{~g}$ dengan perlakuan alumunium sulfate dan ferrous sulfate. Pemberian koagulan memberikan pengaruh nyata terhadap nilai $\mathrm{pH}$ yang dapat dilihat pada Gambar 8. 


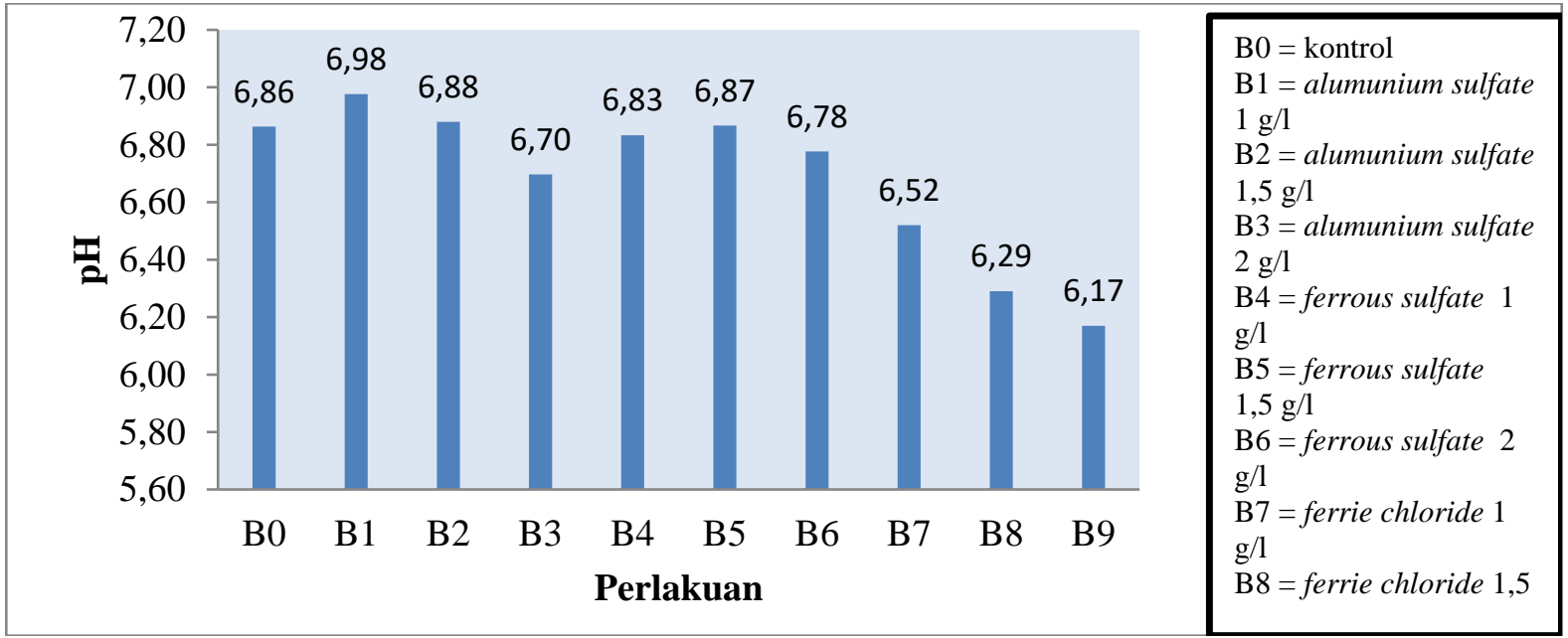

Gambar 8. Derajat kemasaman dari limbah cair industri kelapa sawit akibat perlakuan

Hasil yang terlihat pada Gambar 8, menunjukkan bahwa terjadi penurunan derajat kemasaman setelah pemberian koagulan alumunium sulfate, ferrous sulfate dan ferric chloride. Pemberian alumunium sulfate dengan dosis $2 \mathrm{~g} / \mathrm{L}$ menurunkan $\mathrm{pH}$ air limbah menjadi asam yang $\mathrm{pH}$ awalnya 7,4 menjadi 6,7, ferrous sulfate dengan dosis $2 \mathrm{~g} / \mathrm{L}$ menurunkan $\mathrm{pH}$ menjadi 6,78 sedangkan ferric chloride dengan dosis 2 $\mathrm{g} / \mathrm{L}$ menurunkan $\mathrm{pH}$ menjadi 6,17.

Setelah diberi perlakuan dosis koagulan derajat kemasaman mengalami penurunan, semakin tinggi dosis yang diberikan maka semakin asam limbah cair tersebut. Penurunan $\mathrm{pH}$ ini diduga karena limbah sawit yang sudah netral bereaksi dengan koagulan yang bersifat asam sehingga menghasilkan kondisi air limbah menjadi asam.

Hal ini diperkuat dengan penelitian Norjannah (2015), bahwa penurunan $\mathrm{pH}$ air limbah batik menjadi asam yang terdapat di setiap perlakuan dengan koagulan ferric chloride disebabkan oleh ferric chloride yang bersifat asam dan dapat menetralkan pH yang tadinya basa. Semakin tinggi dosis koagulan ferric chloride maka semakin besar pula presentase menjadi asam yang terjadi.

Pengaruh Jenis dan Dosis Koagulam Terhadap Nilai Total Suspended Solid (TSS)

Total Suspended Solid (TSS) adalah total bahan padatan yang merupakan indikator daya serap air limbah terhadap udara (oksigen). Padatan total terdiri dari padatan tersuspensi (suspended solids) dan padatan terlarut (dissolved solids). Semakin kecil nilai TSS berarti air terolah semakin jernih (Husaini, dkk., 2018). Berdasarkan hasil penelitian ini, kadar TSS sebelum diberi perlakuan sebesar $882 \mathrm{mg} / \mathrm{l}$.

Hasil analisis ragam menunjukkan bahwa pemberian koagulan alumunium sulfate, ferrous sulfate dan ferric chloride memberikan pengaruh nyata terhadap nilai TSS. Hasil uji lanjut BNT pada taraf 5\% disajikan pada Tabel 6 .

Tabel 6. Hasil uji rataan perlakuan koagulan terhadap nilai Total Suspended Solid(TSS)

\begin{tabular}{clc}
\hline No & \multicolumn{1}{c}{ Perlakuan } & Nilai TSS (mg/L) \\
\hline 1 & non koagulan & $860,00 \mathrm{~b}$ \\
2 & alumunium sulfate $1 \mathrm{~g}$ & $579,33 \mathrm{a}$ \\
3 & alumunium sulfate $1,5 \mathrm{~g}$ & $600,00 \mathrm{a}$ \\
4 & alumunium sulfate $2 \mathrm{~g}$ & $620,67 \mathrm{a}$ \\
5 & ferrous sulfate 1 g & $1.243,67 \mathrm{c}$ \\
6 & ferrous sulfate $1,5 \mathrm{~g}$ & $1.376,00 \mathrm{c}$ \\
7 & ferrous sulfate 2 g & $1.641,00 \mathrm{~d}$
\end{tabular}




\begin{tabular}{clc}
8 & ferric chloride 1 g & $432,67 \mathrm{a}$ \\
9 & ferric chloride 1,5 g & $305,33 \mathrm{a}$ \\
10 & ferric chloride 2 g & $278,67 \mathrm{a}$ \\
\hline BNT 0,05 & & 212,58
\end{tabular}

Keterangan : Nilai rata-rata pada kolom yang sama diikuti huruf yang sama menunjukkan tidak berbeda nyata berdasarkan hasil uji BNT taraf $5 \%$.

Berdasarkan hasil uji BNT 5\% terhadap nilai TSS dari pemberian koagulan ferric chloride dan alumunium sulfate memberikan pengaruh nyata terhadap penurunan nilai TSS sedangkan pemberian koagulan ferrous sulfate tidak memberikan pengaruh terhadap penurunan nilai TSS namun menaikkan nilai TSS.

Hasil pengukuran TSS dalam penelitian ini dengan menggunakan koagulan alumunium sulfate, ferrous sulfate dan ferric chloride, sesudah diberi perlakuan pengadukan cepat $200 \mathrm{rpm}$ selama 2 menit, pengadukan lambat 50 rpm selama 10 menit dan pengendapan selama 60 menit didapatkan pada Gambar 9 hasil rata - rata penurunan TSS sesudah diberi penambahan koagulan.

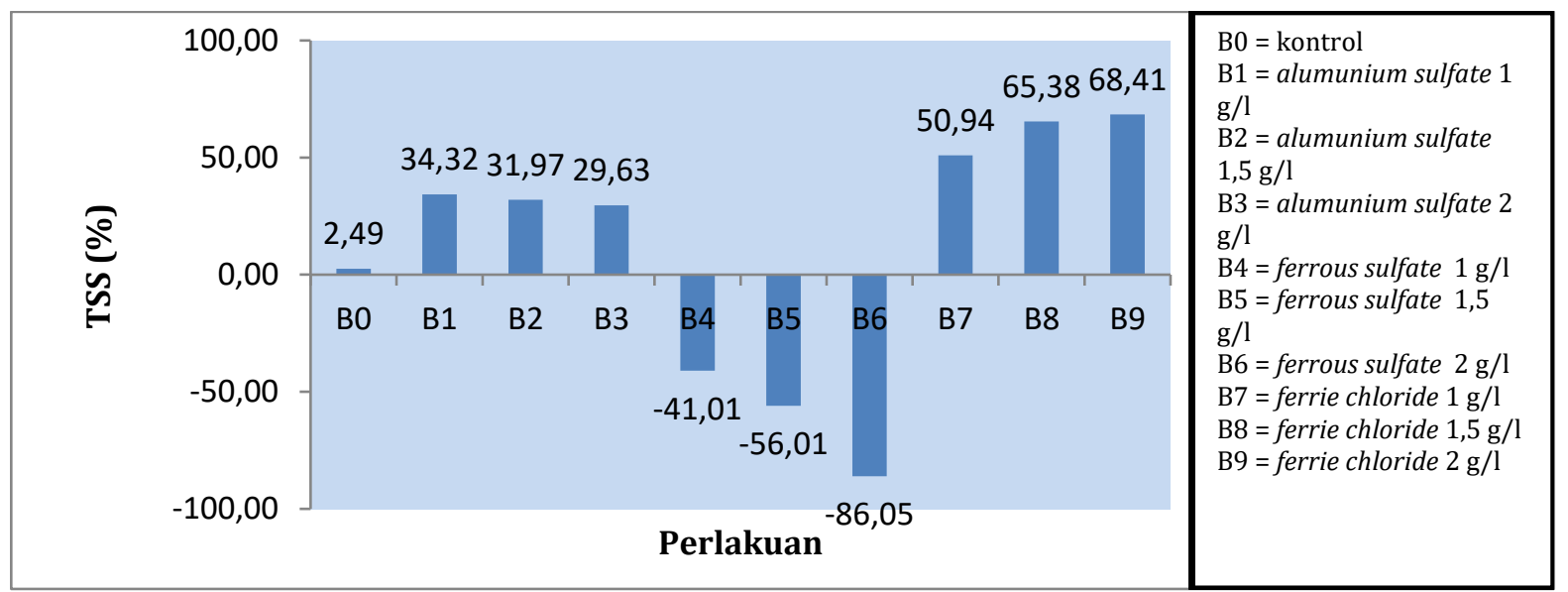

Gambar 9. Penurunan padatan tersuspensi dari limbah cair industri kelapa sawit akibat perlakuan

Gambar 9, menunjukkan bahwa koagulan ferric chloride merupakan koagulan yang paling baik untuk menurunkan konsentrasi TSS dengan dosis 2 g/L. Pada dosis koagulan ferric chloride $2 \mathrm{~g} / \mathrm{L}$ nilai TSS mengalami penurunan hingga $603,33 \mathrm{mg} / \mathrm{L}$ yang awalnya $882 \mathrm{mg} / \mathrm{L}$ menjadi 278,67 $\mathrm{mg} / \mathrm{L}$ (68,41\%). Penambahan koagulan ferric chloride yang semakin tinggi juga akan menurunkan konsentrasi TSS yang semakin tinggi. Sedangkan penggunaan koagulan ferrous sulfate tidak dapat menurunkan konsentrasi TSS melainkan menaikkan konsentrasi TSS yang awalnya $882 \mathrm{mg} / \mathrm{L}$ menjadi $1.641 \mathrm{mg} / \mathrm{L}$ pada dosis 2 g/L $(86,05 \%)$.

Penurunan nilai TSS yang tinggi dipengaruhi oleh adanya proses pengadukan. Menurut Siregar (2008), pada proses ini selama pengadukkan cepat dan lambat flok-flok mulai terbentuk dari polutan-polutan yang tersuspensi koloid yang halus didalam air limbah. Flok-flok tersebut menggumpal yang setelahnya dapat diendapkan atau diapungkan. Proses pengadukan cepat mencampur koagulan yang sudah ditambahkan dan setelahnya terbentuk flok pada proses pengadukan lambat.

Penggunaan dosis koagulan ferrous sulfat yang semakin tinggi akan semakin menaikkan konsentrasi TSS karena pada $\mathrm{pH}$ dibawah 8,5 alkalinitas dan nilai pH air alami terlalu rendah untuk bereaksi dengan tembaga dalam membentuk flok hidroksida besi yang diinginkan, karena reaksi melibatkan oksidasi oleh oksigen terlarut dalam air sehingga perlu ditambahkan 
kapur dengan tembaga untuk mengamankan koagulasi. Proses koagulasi dengan ferrous sulfat menyebabkan perubahan partikel-partikel koloid yang umumnya stabil mengalami suatu ketidakstabilan, dikarenakan penambahan bahan koagulan kedalam air. Koagulan tersebut dapat menempel pada permukaan koloid dan mengubah muatan elektrisnya karena molekul koagulan ferrous sulfate bermuatan positif sedangkan koloid bermuatan negatif.

\section{Pengaruh Jenis dan Dosis Koagulam Terhadap Nilai Turbidity}

Turbidity (kekeruhan) adalah kandungan bahan organik maupun anorganik yang terdapat di perairan

Tabel 7. Hasil uji rataan perlakuan koagulan terhadap nilai Turbidity

\begin{tabular}{clc}
\hline No & \multicolumn{1}{c}{ Perlakuan } & Nilai Turbidity (NTU) \\
\hline 1 & non koagulan & $282,00 \mathrm{a}$ \\
2 & alumunium sulfate 1 $\mathrm{g}$ & $161,33 \mathrm{a}$ \\
3 & alumunium sulfate 1,5 g & $205,33 \mathrm{a}$ \\
4 & alumunium sulfate $2 \mathrm{~g}$ & $226,33 \mathrm{a}$ \\
5 & ferrous sulfate 1 g & $1.853,67 \mathrm{~b}$ \\
6 & ferrous sulfate 1,5 g & $2.534,33 \mathrm{c}$ \\
7 & ferrous sulfate 2 g & $3.404,67 \mathrm{~d}$ \\
8 & ferric chloride 1 g & $206,33 \mathrm{a}$ \\
9 & ferric chloride 1,5 g & $186,00 \mathrm{a}$ \\
10 & ferric chloride 2 g & $126,67 \mathrm{a}$ \\
\hline BNT 0,05 & & 323,23 \\
\hline Keterangan : Nilai rata-rata pada kolom yang sama diikuti huruf yang sama & menunjukkan tidak berbeda nyata
\end{tabular}

Berdasarkan hasil uji BNT 5\% terhadap nilai turbidity dari Pemberian koagulan ferric chloride dan alumunium sulfate memberikan pengaruh nyata terhadap penurunan nilai turbidity sedangkan pemberian koagulan ferrous sulfate tidak memberikan pengaruh sehingga mempengaruhi proses kehidupan organisme yang ada di perairan tersebut. Apabila di dalam air media terjadi kekeruhan yang tinggi maka kandungan oksigen akan menurun, hal ini disebabkan intensitas cahaya matahari yang masuk kedalam perairan sangat terbatas sehingga tumbuhan / phytoplankton tidak dapat melakukan proses fotosintesis untuk mengasilkan oksigen.

Hasil analisis ragam menunjukkan bahwa pemberian koagulan alumunium sulfate, ferrous sulfate dan ferric chloride memberikan pengaruh nyata terhadap nilai turbidity. Hasil uji lanjut BNT pada taraf 5\% disajikan pada Tabel 7. 


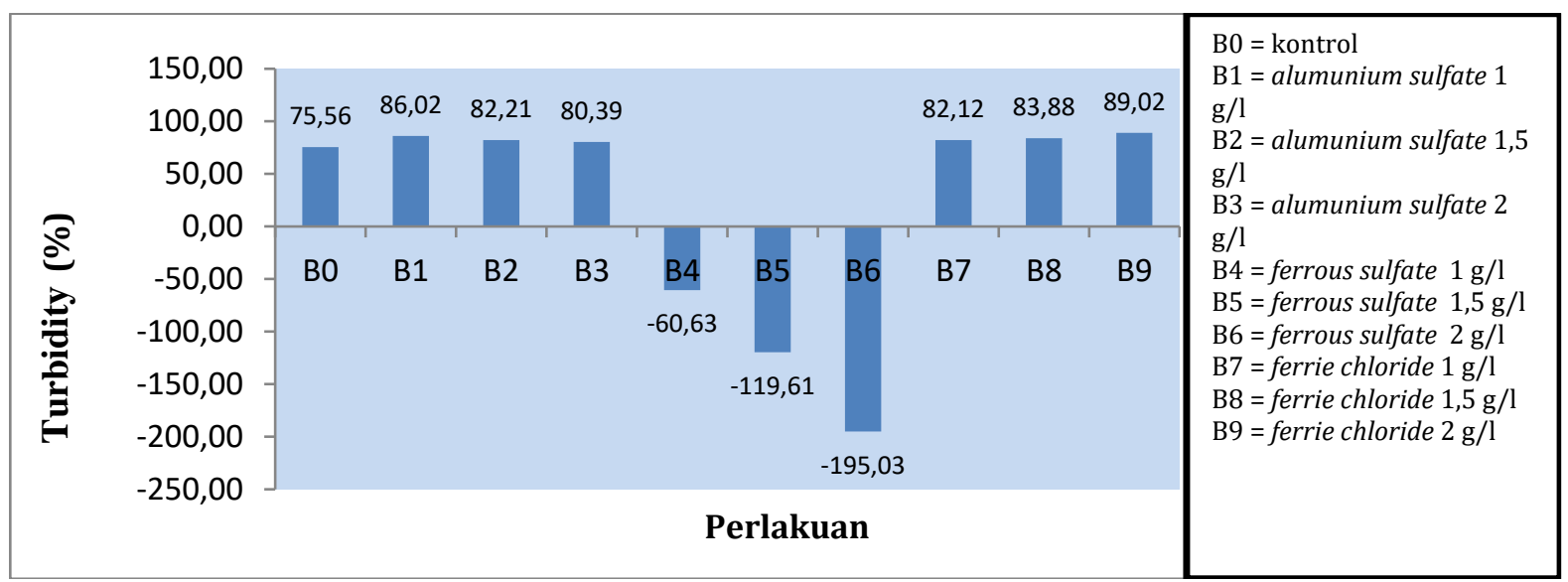

Gambar 10. Nilai turbidity dari limbah cair industri kelapa sawit akibat perlakuan

Hasil yang terlihat pada Gambar 10, menunjukkan bahwa pemberian koagulan ferric chloride dengan dosis $2 \mathrm{~g} / \mathrm{L}$ dapat menurunkan kekeruhan hingga 1.027,33 NTU yang awalnya dari 1.154 NTU menjadi 126,67 NTU (89,02\%). Penambahan ferric chloride yang semakin tinggi maka akan semakin menurunkan tingkat kekeruhan. Pemberian dosis alumunium sulfat dengan dosis $1 \mathrm{~g} / \mathrm{L}$ dapat menurunkan tingkat kekeruhan menjadi 161,33 NTU $(86,02 \%)$. Sedangkan pemberian koagulan ferrous sulfate dengan dosis $2 \mathrm{~g} / \mathrm{L}$ dapat meningkatkan tingkat kekeruhan menjadi 3.404,67 NTU yang tadinya 1.154 NTU sehingga kenaikanya menjadi 195,03 \% dengan demikian semakin tinggi pemberian ferrous sulfate maka semakin tinggi tingkat kekeruhannya.

Menurut Maulidiyah, dkk (2013), Proses koagulasi dengan ferrous sulfat menyebabkan perubahan partikel-partikel koloid yang umumnya stabil mengalami suatu ketidakstabilan, dikarenakan penambahan bahan koagulan kedalam air. Koagulan tersebut dapat menempel pada permukaan koloid dan mengubah muatan elektrisnya karena molekul koagulan ferrous sulfate bermuatan positif sedangkan koloid bermuatan negatif. Ketidakstabilan tersebut menyebabkan flok-flok sulit untuk membentuk padatan yang mengendap maupun mengapung sehingga tingkat kekeruhan akan meningkat.

Perubahan Warna Limbah Cair Kelapa Sawit Akibat Pemberian Koagulan

Warna merupakan karakteristik dari limbah yang paling mudah dikenali karena air limbah biasanya memiliki warna tertentu tetapi tergantung pada kandungan air di limbah tersebut. Warna yang ditimbulkan itu berasal dari adanya proses dekomposisi dari bahan organik, serta menurunnya jumlah oksigen menjadi nol sehingga akan memudarkan warnanya. Tetapi air limbah yang tidak menimbulkan warna tertentu bukan berarti tidak berbahaya.

Dari hasil penelitian didapatkan bahwa warna limbah cair industri kelapa sawit sebelum dan setelah diberi perlakuan ditampilkan pada Tabel 8.

Tabel 8. Hasil uji warna

\begin{tabular}{clll}
\hline No & \multicolumn{1}{c}{ Perlakuan } & \multicolumn{1}{c}{ Warna limbah awal } & Warna setelah perlakuan \\
\hline 1 & non koagulan & Hitam kecoklatan & Coklat kekuningan \\
2 & alumunium sulfate $1 \mathrm{~g}$ & Hitam kecoklatan & Kuning kecoklatan \\
3 & alumunium sulfate $1,5 \mathrm{~g}$ & Hitam kecoklatan & Kuning kecoklatan \\
4 & alumunium sulfate $2 \mathrm{~g}$ & Hitam kecoklatan & Kuning \\
5 & ferrous sulfate $1 \mathrm{~g}$ & Hitam kecoklatan & Coklat kehitaman \\
6 & ferrous sulfate $1,5 \mathrm{~g}$ & Hitam kecoklatan & Coklat kehitaman \\
\hline
\end{tabular}




\begin{tabular}{clll}
\hline 7 & ferrous sulfate $2 \mathrm{~g}$ & Hitam kecoklatan & Hitam kecoklatan \\
8 & ferric chloride $1 \mathrm{~g}$ & Hitam kecoklatan & Kuning \\
9 & ferric chloride $1,5 \mathrm{~g}$ & Hitam kecoklatan & Kuning \\
10 & ferric chloride $2 \mathrm{~g}$ & Hitam kecoklatan & Kuning jernih \\
\hline
\end{tabular}

Warna air limbah dibedakan menjadi dua, yaitu warna sejati dan warna semu. Warna sejati disebabkan oleh warna organik yang mudah larut serta beberapa ion logam. Sedangkan warna semu disebabkan oleh air yang mengandung kekeruhan atau adanya bahan tersuspensi dari warna sejati serta karena adanya bahan-bahan tersuspensi termasuk koloid (Yulianto, dkk., 2009).

Dari hasil pengamatan diatas dapat dilihat bahwa warna limbah tanpa perlakuan berwarna 7,5 Y $3 / 2$ (hitam kecoklatan) yang artinya bahwa air tersebut mempunyai nilai hue $=7,5 \mathrm{Y}$, value $=3$ dan chroma $=2$, yang secara keseluruhan disebut warna hitam kecoklatan. Pemberian alumunium sulfate dengan dosis $2 \mathrm{~g} / \mathrm{L}$ mampu merubah warna limbah menjadi $5 \mathrm{Y}$ 7/8 (kuning kecoklatan) dan pemberian ferric chloride dengan dosis $2 \mathrm{~g} / \mathrm{L}$ mampu merubah warna limbah menjadi 5 Y 8/4 (kuning jernih), perubahan ini disebabkan karena kandungan bahan organik pada limbah cair kelapa sawit terikat oleh partikel koagulan yang membentuk flokflok padatan yang mengendap. Sedangkan pemberian ferrous sulfat dengan dosis $2 \mathrm{~g} / \mathrm{L}$ merubah warna limbah menjadi 2,5 Y 3/2 (coklat kehitaman), dimana pemberian koagulan ini tidak mampu merubah warna dikarenakan ferrous sulfate tidak mudah larut dalam air sehingga bahan organik tidak mampu terikat oleh padatan koagulan.

\section{KESIMPULAN DAN SARAN}

Penelitian ini dapat disimpulkan bahwa terdapat hubungan sikap kerja, beban kerja, umur, masa kerja, indeks massa tubuh dengan keluhan musculoskeletal disorders pada pekerja pengangkut barang di Pasar Panorama Kota Bengkulu dan Faktor yang paling berhubungan dengan keluhan musculoskeletal disorders adalah sikap kerja dengan $p=0,000$ dan OR 87,871. Sebaiknya pekerja dapat mengubah sikap kerja yang tidak ergonomis menjadi ergonomis dan menghindari sikap kerja yang memiliki tingkat resiko pekerjaan yang tinggi.

\section{KEPUSTAKAAN}

1. Amalia O. Aktifitas Analisis Faktor Risiko Muskuloskeletal Disorders (MSDs) pada Buruh Informal Pasar Grosir Blok F Tanah Abang Jakarta Pusat [Skripsi]. Jakarta: UIN Syarif Hidayatullah; 2010.

2. Depkes RI. (2003). Profil Kesehatan Indonesia. Jakarta: Depkes RI; 2003.

3. Ohlsson K, Attewel RG, Skerfving S. Self-reported Symptoms in The Neck and Upper Limbs of Female Assembly Workers. Scand Journal Work Environment Health. 1989. e-journal 15 : pp.75-80.

4. Oktaria S. Posisi Duduk yang Sehat dan Benar Saat Bekerja [Internet]. 2015. Available from: http://www.klikdokter.com.

5. Pratiwi HM. Beberapa Faktor yang Berpengaruh terhadap Keluhan Nyeri Punggung Bawah pada Penjual Jamu Gendong. Semarang. Jurnal Promosi Kesehatan Indonesia. 2009 : 4 (1): 6167.

6. Suma'mur. Higiene Perusahaan dan Kesehatan Kerja. Jakarta: Sagung Seto; 2004.

7. Tarwaka. Ergonomi Industri DasarDasar Pengetahuan Ergonomi Dan Aplikasi Ditempat Kerja. Surakarta: Harapan Press; 2015. 